\title{
Habitat conservation in Italy: the state of the art in the light of the first European Red List of Terrestrial and Freshwater Habitats
}

\author{
D. Gigante ${ }^{1}$ - A. T. R. Acosta ${ }^{2}$ - E. Agrillo ${ }^{3}$-S. Armiraglio ${ }^{4}$-S. Assini ${ }^{5} \cdot$ F. Attorre ${ }^{3}$ - S. Bagella ${ }^{6} \cdot$ G. Buffa $^{7} \cdot$ L. Casella $^{8}$. \\ C. Giancola ${ }^{9} \cdot$ G. P. Giusso del Galdo ${ }^{10} \cdot$ C. Marcenò ${ }^{11} \cdot$ G. Pezzi ${ }^{12} \cdot$ I. Prisco $^{2} \cdot$ R. Venanzoni ${ }^{1}$ (1) - D. Viciani ${ }^{13}$
}

Received: 4 February 2018 / Accepted: 21 March 2018 / Published online: 5 April 2018

(c) Accademia Nazionale dei Lincei 2018

\begin{abstract}
The importance of taking into account ecosystems, plant communities and habitats for the development of biodiversity conservation strategies is increasingly acknowledged. Recently, the first ever European Red List of Habitats was produced, which provided an evaluation of the extinction risk of EUNIS-based natural and semi-natural habitats in Europe. As assessment unit, it used the habitat intended as a plant community, thus representing a landmark for the role of vegetation science in nature conservation. In the present paper, the results of the European Red List of Habitats are analyzed at the national scale with specific reference to the terrestrial and freshwater habitat types occurring in Italy. More than three-quarters of the assessed European habitat types were recognized for the Italian territory. The distribution of the threat categories reflects approximately the situation at the EU28 level. About 35\% of the assessed habitat types are referred to a threat category; no critically endangered habitat is present in Italy. The most frequently used criteria are those related to a reduction in quantity. Some critical issues arising from the analyses are discussed. In particular, the presence of knowledge gaps is pointed out, with remarkable reference to the poor availability of spatial and quantitative data, severely affecting the application of the criteria adopted for the assessment. Descriptions of habitat types from Italy are reported, some of which are representative, emblematic or even exclusive to the Italian territory. The outcomes of the analysis represent the starting point for the future development of a national-scale Red List of Habitats. Results also emphasized how habitat types with a too broad definition pose a limit to a proper evaluation of the regional biogeographic variability, often very high in Italy, with local floristic and phytocoenotic peculiarities which do not find room in the adopted European typology. This is the reason why the development of national subtypes stands as a necessary step for the development of a realistic and effective assessment at the national scale.
\end{abstract}

Keywords Assessment $\cdot$ Biodiversity $\cdot$ Plant community $\cdot$ Risk of extinction $\cdot$ Threat

\section{Introduction: habitat red-listing, concepts and aims}

The importance of biodiversity as a factor controlling the processes underpinning ecosystem services has been increasingly recognized (Balmford et al. 2002; Millennium Ecosystem Assessment 2005; Cafaro and Primack 2014). Over time, it has led to several national and international agreements, frameworks and directives aimed at

This peer-reviewed contribution is from the European Vegetation Survey working group established in 1992 by Alessandro Pignatti and colleagues in Rome.

D. Gigante

daniela.gigante@unipg.it

Extended author information available on the last page of the article counteracting and halting biodiversity loss (see, e.g., CITES 1973; United Nations 1976, 1992, 2015; European Commission 1992, 2011; Secretariat of the Convention on Biological Diversity 2010). Traditionally, the evaluation of biodiversity state and trends mainly relied on the species level, with the evaluation of their extinction risk and the compilation of red lists of threatened taxa (Mace et al. 2008; IUCN 2012, 2013). Efforts to standardize the assessment process led to the International Union for Conservation of Nature (IUCN) Species "Red Lists", which aim at reflecting the extinction risk of many taxa and setting priorities for their conservation, thereby making governments and society aware of possible loss of biodiversity (Baillie et al. 2004; Butchart et al. 2004; McCarthy et al. 2008).

However, the importance of taking into account ecosystems, plant communities or habitats has been increasingly 
acknowledged for the implementation of successful conservation strategies and priorities, which require suites of complementary measurements. Moreover, the use of biological communities/ecosystems may more efficiently represent the biological diversity as a whole and act as a surrogate for species yet not or poorly known (Noss 1996; Cowling et al. 2004; Nicholson et al. 2009; Kontula and Raunio 2009; Testi et al. 2010; Rodríguez et al. 2011, 2012; Galdenzi et al. 2012; Berg et al. 2014; Viciani et al. 2014; Izco 2015; Keith et al. 2017).

Attempts to compile lists of threatened ecosystems/plant communities/habitats date back to the early 1980s (e.g., Moravec et al. 1983; Schulte and Wolf-Straub 1986). In these first trials, the assessment was essentially expert based, applying very heterogeneous criteria, ranging from rarity to distribution, from species composition to human pressure, from naturalness to esthetic value (Blab et al. 1995; Noss et al. 1995; Paal 1998). Unfortunately, insufficient attention to key conceptual bases and their appropriate use has led, in some cases, to inconsistent applications. The 92/43/EEC "Habitats" Directive (hereafter: HD) was the first EU policy legal document to provide a list of habitats of conservation concern (Annex. 1) and parameters for the assessment of their conservation status; however, its methodological criteria of inclusion have remained largely obscure. Later, several frameworks had been proposed for assessing the conservation status of plant communities or ecosystems, mainly at the regional or national scale (Essl et al. 2002; Walker et al. 2006; Kontula and Raunio 2009; Biserkov 2011; Lindgaard and Henriksen 2011). Although generally grounded on robust ecological theories, all these approaches show more or less relevant differences and disagreements.

Recently, two important projects were developed focusing on the use of transparent, mostly quantitative criteria, so as to be acknowledged as an internationally valid approach for ecosystem/habitat red-listing. At global level, the IUCN council formally endorsed the methodological protocol proposed by Keith et al. $(2013,2017)$, which aims at establishing a global Red List of Ecosystems (RLE). Criteria and categories are meant to provide a reliable global framework for monitoring the status of ecosystems and complement The IUCN Red List of Threatened Species (IUCN 2016, Bland et al. 2017). At the European level, the first European Red List of Habitats (hereafter: EU-RLH) was produced, providing an evaluation of the extinction risk of natural and semi-natural terrestrial, freshwater and marine habitats in Europe, based on the evaluation of their current and historical, qualitative and quantitative trends of change (Janssen et al. 2016; Gubbay et al. 2016). The latter document is somehow a by-product of the first one, starting from the same conceptual framework (Rodríguez et al. 2012; Keith et al. 2013, 2017; Bland et al. 2017), although focusing on a different evaluation unit, i.e., the habitat, and adjusting the assessment methodology based on a formerly ad hoc feasibility study (Rodwell et al. 2013).

In the present paper, the results of the EU-RLH are analyzed at the national scale, i.e., with specific reference to those habitats whose presence has been recognized for Italy. The main aims are (1) to provide an overview of the risk of extinction of habitat types, as assessed at the EU scale, occurring in Italy, focusing on the possible repercussions of the EU-RLH on habitat conservation at the national level; (2) to explore the inconsistencies and gaps arising from this first application of the red-listing approach to habitat types occurring in Italy; (3) to implement ideas and feasible solutions for the development of a national-scale Red List of Habitats.

\section{Overview and methodological benchmarks: the European Red List of Habitats}

The European Commission (DG Environment) recently applied to habitats the "red-listing" approach already used for animal and plant species, supporting the first ever EURLH. In this document, the current threat level and future prospects of European habitats are provided. The EU-RLH is the result of the joint work of 49 experts and around 150 territorial data providers, from almost all the European countries. The project was subdivided into two main areas, assessing separately the terrestrial/freshwater (TFH) and the marine habitats $(\mathrm{MH})$. The overall results have been published in two official publications of the European Commission (Janssen et al. 2016; Gubbay et al. 2016). In the present paper, we only take into account the TFH. For detailed information about descriptions, protocols, criteria and thresholds, see Janssen et al. (2016).

The evaluation was conducted at two geographical scales, considering the EU28 territory and a larger area (called EU28 +) including also Switzerland, Norway, Iceland and the non-EU Balkan countries (plus the North Atlantic, Baltic, Mediterranean and Black Seas for the marine habitats), for a total of 33 countries.

The habitat typology was developed ad hoc for the EURLH project, based on the EUNIS classification (EUropean Nature Information System, Davies et al. 2004; EUNIS 2007) at level 3, considered as the most appropriate framework for the assessment of terrestrial and freshwater habitats at the European level, updated and partly rearranged based on the most recent scientific advances in vegetation science (Janssen et al. 2016). The EU-RLH typology strongly contributed to the ongoing revision of the EUNIS classification (EEA 2015; Schaminée et al. 2012, 2013, 2014, 2015, 2016). It is worth highlighting that it represents an entirely new tool and covers a much wider range of habitat types than those 
legally protected under the "Habitat" Directive. Indeed, the list of habitats included in HD Annex I (European Commission 1992, 2013) excludes many types of vegetation with conservation relevance (see, e.g., Lastrucci et al. 2014; Angiolini et al. 2017).

For each habitat type, a cross reference is provided both to the HD Annex I habitats and to the alliances reported in the phytosociological classification of European vegetation (Mucina et al. 2016). Additionally, a large set of information is added for every habitat, including a full description, color images, distribution maps (although mostly not exhaustive), occurrence and trends in each country and lists of main threats. The threat categories were based on the EIONET Reference list and the IUCN-CMP Unified Classification, v. 3.2 (2011), both derived from Salafsky et al. (2008). The complete factsheets for each TFH are freely available at https ://forum.eionet.europa.eu/european-red-list-habitats/library.

The TFH types assessed in the EU-RLH are 228 in EU28 and 233 in EU28+, subdivided into seven macro-categories: "A/B-Coastal": coastal saltmarshes, beaches, dunes and cliffs (29 habitat types in EU28, 30 in EU28 +); "C-Freshwater: lakes, streams, rivers and springs" $(26,26)$; "DMires and bogs" (13, 13); E- "Grasslands: dry and wet pastures and meadows, steppes, alpine grasslands and tall-herb vegetation" $(53,53)$; "F-Heathland and scrub: heath, scrub and tundra" (36, 38); "G-Forest: broadleaved and coniferous forests" (42, 42); "H-Sparsely vegetated: screes, cliffs, rock, snow and ice habitats" $(29,31)$, the latter including also the only type from the group "I-Regularly or recently cultivated agricultural, horticultural and domestic habitats" (i.e., the TFH I1.3-Arable land with unmixed crops grown by low-intensity agricultural methods).

Based on ad hoc thresholds developed just for the EURLH assessment, 37\% of all the types (32\% in EU28+) fall into the threatened categories critically endangered $(2,2 \%)$, endangered $(11,10 \%)$ and vulnerable $(24,20 \%)$, while $12 \%$ (both in EU28 and EU28+) were considered as near threatened. Only a small amount of TFH types (5\% in EU28, 6\% in EU28 +) could not be evaluated for lack of robust data and were considered as data deficient. The most severely threatened TFH types are grasslands, freshwaters and coastal habitats. The most used and decisive criteria were, with decreasing frequency: the quantitative trend over 50 years (Cr. A1), the qualitative trend over 50 years $(\mathrm{Cr}$. C/D1) and the quantitative historical decline (Cr. A3). The Criterion E, specifically developed for the EU-RLH, based on the habitat "collapse" (meant as the probability that its defining biotic/ abiotic features are lost and the characteristic native biota are no longer sustained), was used only once, i.e., for the type D3.1 Palsa mire (Janssen et al. 2016).

One of the main critical issues, particularly true for most of the S-European countries, is represented by the very poor availability of spatial and quantitative data, both from the present and the past. This lack of knowledge still nowadays stands as a strong constraint to the application of the criteria adopted for the assessment.

\section{Data sources: the Italian contribution to the EU-RLH}

Starting from the huge, though patchy knowledge currently available for the Italian habitats and plant communities, the first step was the identification of the TFH types occurring in Italy from the European list. This has implied a massive work of collection, analysis and review of existing sources, most of which only limited to small portions of the country, which highlighted the absence of a national-scale quantitative overview of habitats and plant communities.

The principal wide-scale sources of quantitative data were represented by the "Carta delle Serie di Vegetazione d'Italia", a cartographic document reporting on the potential natural vegetation of Italy (Blasi 2010), and the Corine Land Cover map (European Environmental Agency 2007). The "Carta della Natura", a map of habitats based on CORINE Biotopes classification, was also used where available (Angelini et al. 2009).

The overlap of these cartographic sources provided relevant data about the distribution of TFH types, allowing a reliable quantification, or in some cases, an estimate of their current distribution. For those TFH types totally or partially corresponding to HD Annex I habitats, further qualitative and quantitative information was also obtained using the results of the third Italian Report ex-Art. 17 (Genovesi et al. 2014) and from a wide variety of technical reports and management plans (e.g., Natura 2000 Sites Management Plans), by way of a cross reference with the "Manuale Italiano di interpretazione degli habitat della Direttiva 92/43/CEE" (Biondi et al. 2009, 2012). Moreover, additional information was obtained from non-spatialized data such as the Prodrome of the Italian vegetation (Biondi et al. 2014; Biondi and Blasi 2015), along with the huge scientific production focused on vegetation science and phytosociological studies available for the Italian territory, mostly dating back to the last five decades.

Due to the patchy character of the data, a large part was played by expert's knowledge, mostly in the form of estimates and inferences. Although in need of calibration and weighting procedures when aggregating responses of different experts, this type of unformalized knowledge still represents an indispensable and irreplaceable component of environmental studies (Krueger et al. 2012; Javeline et al. 2013; Bland et al. 2017). 
Table 1 Number of TFH types assessed in the EU-RLH present in IT, EU28 and EU28+, subdivided per macro-categories

\begin{tabular}{lllc}
\hline TFH macro-categories & EU28 & EU28 + & IT (\% EU28) \\
\hline A/B-Coastal & 29 & 30 & $10(34.5)$ \\
C-Freshwater & 26 & 26 & $26(100)$ \\
D-Mires and bogs & 13 & 13 & $7(53.8)$ \\
E-Grasslands & 53 & 53 & $38(71.7)$ \\
F-Heathland and scrub & 36 & 38 & $25(69.4)$ \\
G-Forests & 42 & 42 & $32(76.2)$ \\
H-Sparsely vegetated & 29 & 31 & $21(72.4)$ \\
\hline
\end{tabular}

The Italian percentage of occurrence has been calculated with reference to EU28

\section{Results: the role of Italian biodiversity in the first European Red List of Habitats}

A high number of RLH terrestrial and freshwater habitat types were recognized for the Italian territory to date, namely 159 , accounting for $69.7 \%$ of all TFH types surveyed throughout EU28 (68.2\% with reference to EU28+).
Considering the seven macro-categories (Table 1), it can be noticed that all the "Freshwater" habitats (100\%) occur in Italy, while the "Coastal habitats" (34.5\%) and "Mires and bogs" (53.8\%), are the macro-categories with the lowest proportion of types found in Italy.

When considering the level of threat of each single habitat type (Fig. 1), there is a different distribution of the threat categories at the EU28+ scale, compared to EU28. This is due to different outcomes of the assessments at different territorial scales. In most of these cases (13 out of 14), the threat results lower in EU28+ than in EU28, where the rate of VU and CR appears to be higher, while the rate of $\mathrm{LC}$ and DD is lower than in EU28+. The distribution of the threat categories in Italy reflects approximately the situation at the EU28 level, but with some small differences for the proportion of VU and NT. Surprisingly, no critically endangered (CR) habitat is present in Italy (Fig. 1). With regard to the macro-categories, the assessment produced rather differentiated results (Fig. 2). The group "Heathland and scrub" includes a vast majority (more than $80 \%$ ) of TFH types falling in the category LC. On the other side, the highest rate of threatened types is that of "Mires and bogs" (100\%), followed by "Grasslands" (57.9\%) and "Freshwater" (46.2\%).
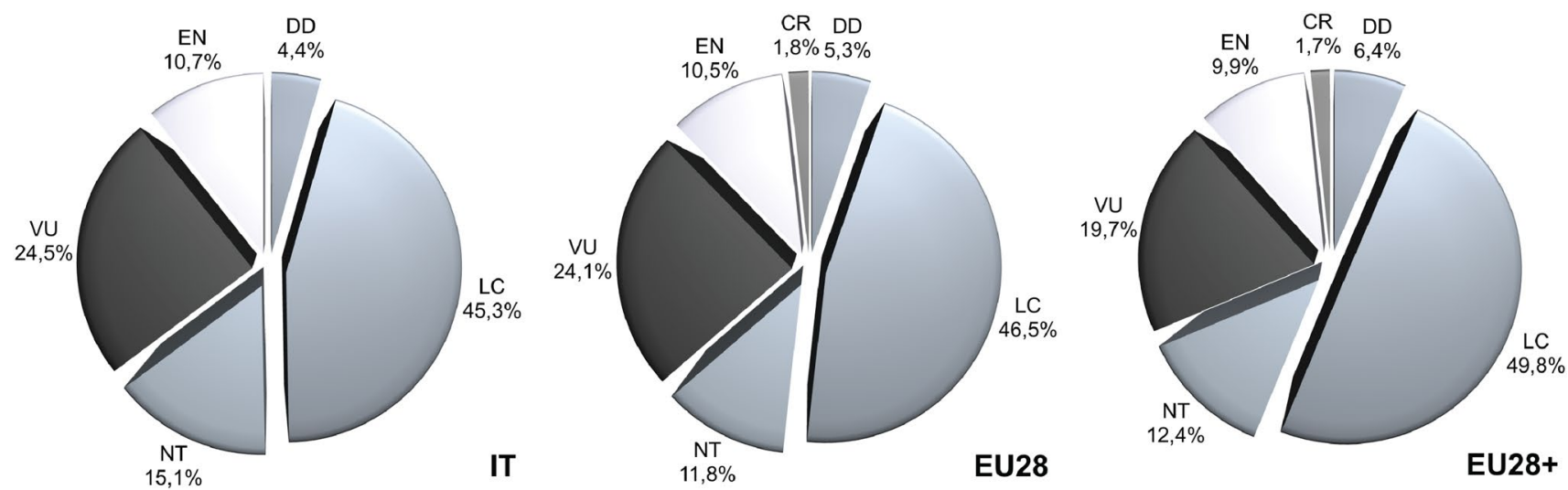

Fig. 1 Different threat levels resulting from the assessment of the TFH types in the EU-RLH, with reference to Europe (EU28 and EU28+) and Italy (IT)

Fig. 2 Different threat levels resulting from the assessment of the TFH types in Italy, subdivided per habitat macrocategories

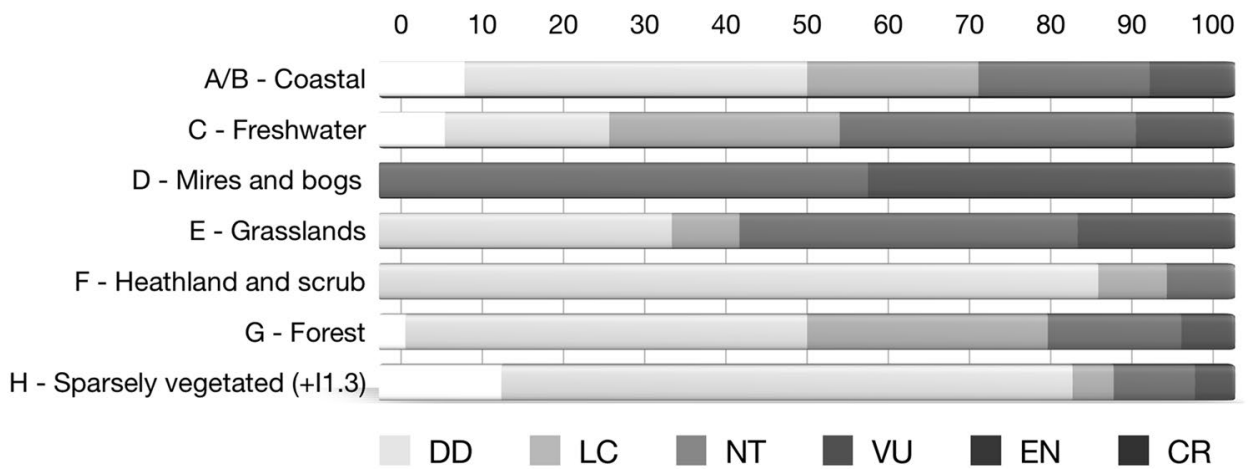


With reference to the different criteria decisive for the RLH assessment, the Italian scenery is almost comparable with the EU28 and EU28+ situation (Figs. 3, 4). The most frequently used criteria were those related to a reduction in quantity, cumulatively accounting for more than half of all the TFH types, especially based on the present (A1, 40\%) and historic (A3,15\%) decrease. The second most used criterion was C/D1 (34\%), i.e., a reduction in abiotic and/or biotic quality during the last 50 years. The criterion $\mathrm{E}$ was not applied for any of the types present in Italy.

Hereafter, we report some descriptions of emblematic and representative habitat types of the Italian territory. The species nomenclature is updated according to the most recent reviews and matches with the database AnArchive (Lucarini et al. 2015).

\subsection{Mediterranean and Black Sea shifting coastal dune (B1.3b)}

This habitat type includes perennial plant communities colonizing embryonic and shifting "white" dunes (foredunes), affected by winds, waves, salt spray and summer drought.
The horizontal rhizomes of Elymus farctus (Viv.) Runemark ex Melderis [syn. Elytrigia juncea (L.) Nevski subsp. jun$c e a]$ in the embryonic dunes contribute to the sand accumulation and the spread of other species, feeding the dune construction process. More inland, white shifting dunes are characterized by the dominance of Ammophila arenaria (L.) Link subsp. arundinacea $\mathrm{H}$. Lindb., a very important rhizomatous dune species as it constitutes a barrier for windblown sand, contributing to the increase of dune height. Embryonic dunes and shifting dunes are considered to be two different habitats in the Annex I of the Habitat Directive, 2110 and 2120, respectively, although they are often not clearly separated (Feola et al. 2011; Prisco et al. 2012).

The habitat is more or less restricted to the Mediterranean and Black Sea biogeographic regions, but it could be also found along the Atlantic coasts of the Iberian Peninsula and Macaronesia.

The quantitative data provided by the European countries is relatively satisfactory, at least for the current area of the habitat. On the contrary, literature data for the historical area of the habitat is quite scarce, making it necessary to estimate indirectly trends in quantity and quality by expert's
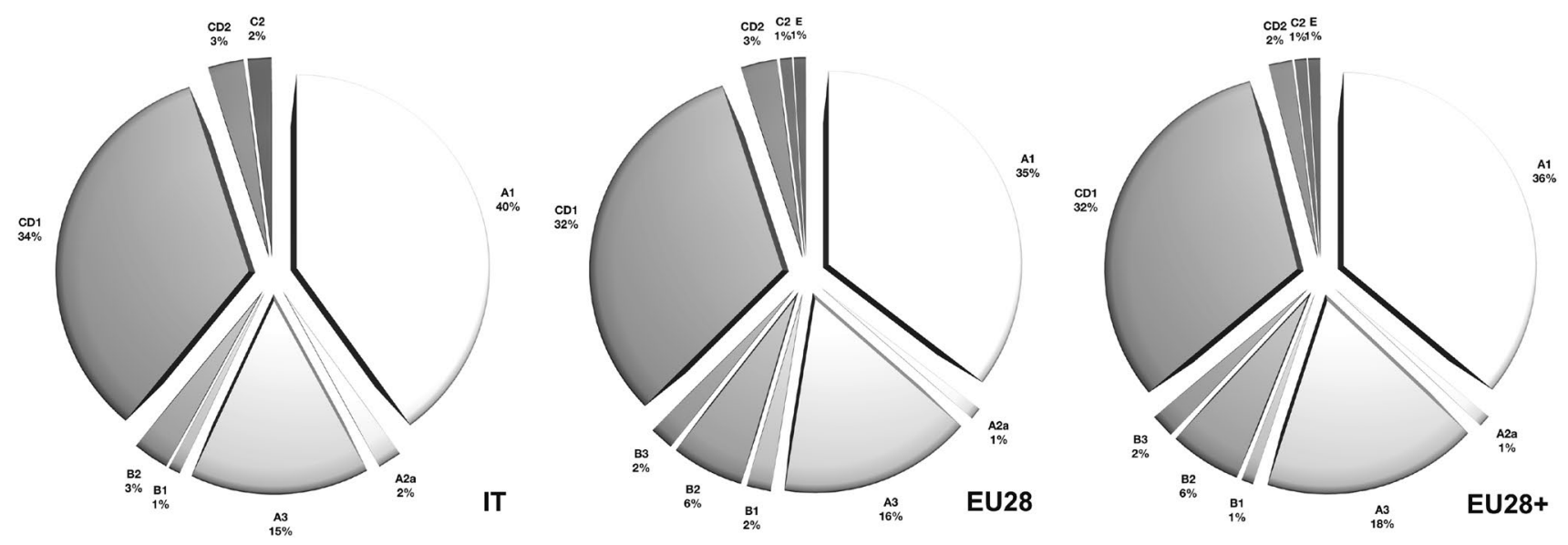

Fig. 3 Proportion of the different criteria decisive for the RLH assessment in Italy, EU28 and EU28+; threatened and near threatened habitats have been taken into account

Fig. 4 Proportion (\%) of the different criteria decisive for the RLH assessment in Italy, subdivided per habitat macrocategories; threatened and near threatened habitats have been taken into account

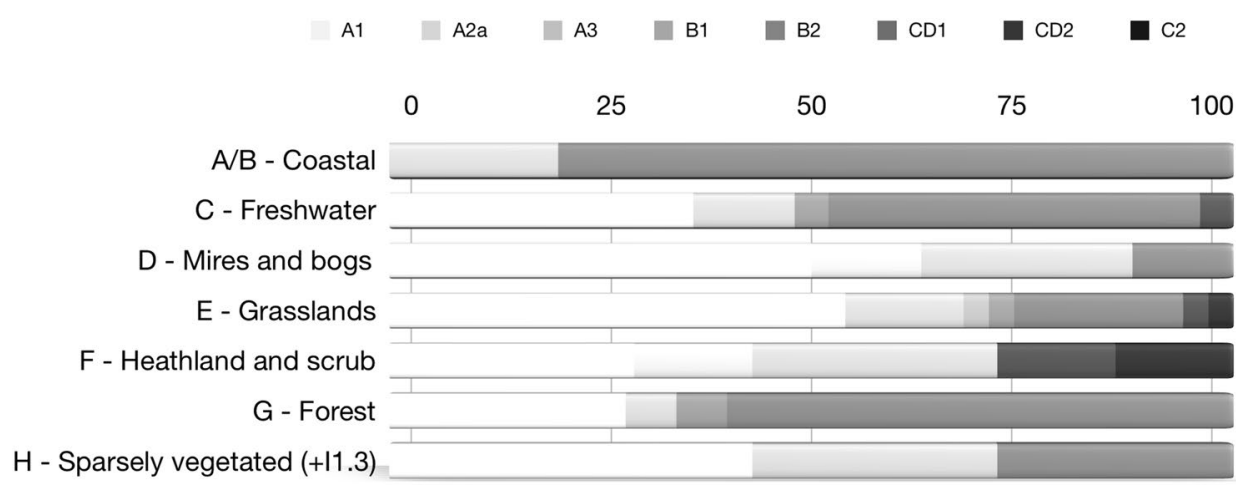


knowledge. Consequently, the confidence in the assessment of the habitat's conservation state could be considered medium.

Although this habitat has suffered historically a large reduction in quantity due to human pressure, especially in Italy and Spain, the habitat is assessed as Least Concern under Criterion A (reduction in quantity). The percentage of area declining in extent over the last 50 years is about $21 \%$, while considering a larger time span (since 0-250 years ago) it is estimated at about $25 \%$. The habitat's geographical distribution is above the thresholds for Criterion B, making its assessment as Least Concern. The reduction in quality (Criterion C/D1) over the last 50 years on average affected about $47 \%$ of the current area, with a relative severity of degradation of about $68 \%$. As more than $50 \%$ of the habitat is affected negatively, it results in the category vulnerable.

It is likely that the main threats affecting this habitat (mainly recreational activities and coastal erosion) could increase and will cause continuing declines within the next 20 years. This means that the habitat could be relatively more endangered and deserves extra attention from a nature conservation point of view. Moreover, shifting dunes with A. arenaria are probably facing more risks than embryo dunes; so; where possible these subtypes should be considered separately.

\subsection{Mediterranean temporary water body (C1.6b)}

This habitat type includes shallow to very shallow temporary pools and seasonally wet depressions, mostly oligotrophic, colonized by pioneer ephemeral freshwater vegetation with annual amphiphytes (Mediterranean spring annuals/therophytes), germinating in the aquatic phase and reproducing in the terrestrial ecophase, and dwarf geophytes. It is distributed in the Mediterranean and warm Atlantic of Europe and in Northern Africa with a greater abundance and quality in the westwards (Quézel 1998). Italy represents a critical area for this habitat, considering the central position in the Mediterranean basin. Indeed, even this is not the extreme margin of the areal distribution of the habitat, some rare or characteristic species are endemic to this territory, or this region represents their eastern margin (Bagella and Caria 2013; Ernandes et al. 2017).

Data availability in EU28 could be sufficient concerning the current and recent past (last 50 years distribution and quality). Information on long historical trend in quantity and quality is instead completely missing. This lack represents a limit in the assessment because the awareness of this habitat relevance is quite recent, while the recognition of its real distribution has been historically neglected (Bagella et al. 2016). The massive destruction of the habitat is probably to be dated in many regions at the first decades of 1900, when large wet areas were reclaimed because of being considered unhealthy. Data availability in EU28+ is definitely lower. For these reasons, the assessment probably reflects a situation more optimistic than the real one. On the basis of the available information, the habitat was assessed as VU based on criteria C/D1 for EU28 and EU28+.

The criticality of this habitat type is due to its intrinsic characteristics: it occurs in relatively small spots across a wide range with a very fragmented distribution, is often poorly identified and its importance is largely unappreciated, leaving it vulnerable also to unintentional destruction (Grillas et al. 2004).

\subsection{Small-sedge base-rich fen and calcareous spring mire (D4.1a)}

This habitat includes small sedges and brown-moss communities of calcareous fens, with soligene or topogenic origin. The habitat presents a mosaic-like structure of ponds, springs, marshes, grasslands and brown-moss carpets developed on permanently waterlogged soils with base-rich water supply. Characteristic species are Parnassia palustris L., Tofieldia calyculata (L.) Wahlenb., Eriophorum latifolium Hoppe, Carex davalliana Sm., Liparis loeselii (L.) Rich. and Menyanthes trifoliata L. Bryophytes, e.g., Campylium stellatum (Hedw.) Lange \& C. E. O. Jensen and Palustriella commutata (Hedw.) Ochyra [syn. Cratoneuron commutatum (Hedw.) Roth], are of great importance for the biodiversity of this habitat. It is an extremely sensitive environment; nevertheless, in the past the natural supply of base-rich water was sufficient to maintain the fen vegetation, while in few past centuries changes in hydrological conditions and pollution affected its conservation status. This habitat is included in the Habitat Directive Annex I type "7230-Alkaline fen". It occurs through lowlands and mountains of nemoral Europe and more locally in the boreal zone. In the limestone massifs of Alps and Carpathians, this habitat is quite rich and diverse, especially in the primary, likely old, sites, developing around natural springs and seepage lines of calcium-rich water. In Italy, it is well represented in the Alps, where it is very rich and diverse in composition, while it appears more discontinuously in C- and S-Apennines where it presents a relic distribution and is characterized by paucispecific communities with a high biogeographic value.

The total area is very low, as the habitat almost everywhere occurs in small stands. The classification into the Endangered (EN) category seems realistic. The application of $\mathrm{A} 1$ and $\mathrm{A} 3$ criteria describes decline in extent over the last 50 years and a longer time frame $(50.4 \%$ decline in quantity for recent trend in EU28 and 67\% in historical trend). Nevertheless, the real decline is probably higher than reported, since the assessment is affected by the low values indicated for Sweden (ca. - 20\%) hosting almost half of the total European area. Moreover, the subtypes that cover 
smaller areas and occur outside Sweden, Ireland and Estonia are even more threatened and, if assessed separately, the Critically Endangered category should be expected.

This habitat declined strongly during the last century, both in range and area with a corresponding loss in species composition. The main causes are hydrological dysfunction (drainage and flooding), abandonment of traditional management, agricultural pollution and nutrient input. This habitat became dramatically rare in Italy and a loss of surface area of more than $80 \%$ can be derived from literature data, as massive destruction occurred mostly during the nineteenth and twentieth century. Recently, this loss seems to have become less impressive, due to the conservation measures that act over the majority of the residual sites, even if the habitat function has been highly affected by human impacts. The habitat is still found in all regions of its historical distribution, while the potential range is highly affected by climate-driven factors, resulting in a long-term prediction of a massive loss in the Mediterranean region.

\subsection{Sub-Mediterranean xeric open grassland of skeletal calcareous and ultramafic soils (E1.1e)}

This herbaceous habitat type is exclusive to Italy (i.e., endemic) and includes sub-Mediterranean dry grasslands developed on base-rich bedrocks and maintained by extensive grazing. Besides hemicryptophytes and annuals, which especially colonize the micro-clearings due to the discontinuity of the sward, these grasslands often host dwarf shrubs, with a rich chamaephytic component, showing a transitional character between the temperate dry grasslands and the Mediterranean garrigues. They are generally species rich and frequently host endemic or subendemic plants such as Centaurea ambigua Guss., Crepis lacera Ten., Erysimum pseudorhaeticum Polatschek, Festuca inops De Not., F. robustifolia Markgr.-Dann., Phleum ambiguum Ten. and Stipa dasyvaginata Martinovský subsp. apenninicola Martinovský et Moraldo.

They occur in the inner territories of the Italian Peninsula, especially in the Apennines where they give rise to a distinctive cultural landscape. From the phytosociological point of view, this type of habitat has been referred to the endemic alliances Cytiso spinescentis-Bromion erecti Bonin 1978 and Seslerio nitidae-Caricion macrolepidis Ubaldi 1997, both considered by the Italian Prodrome (Biondi and Blasi 2014) as synonyms of the alliance Phleo ambigui-Bromion erecti Biondi, Ballelli, Allegrezza and Zuccarello ex Biondi and Galdenzi 2012. The vegetation types belonging to the alliance Alyssion bertolonii E. Pignatti et Pignatti 1977, only occurring in NW Apennines on serpentine outcrops and ophiolithic substrata, are also included in this type. This habitat corresponds to part of Annex I habitat " $6210\left(^{*}\right)$
Semi-natural dry grasslands and scrubland facies on calcareous substrates (Festuco-Brometalia)".

The habitat E1.1e was assigned to the category vulnerable (VU) both in EU28 and EU28+, based on a strong reduction in abiotic and/or biotic quality (Criteria C/D1).

Among the major pressures and threats that put these dry grasslands at risk of conservation, the abandonment of traditional pastoral activities plays a key role, since these activities have drastically decreased all over the mountain areas in the last decades (Viciani et al. 2017). A continuous future qualitative reduction can realistically be expected, mainly due to the ongoing abandonment and the related successional processes, with drastic changes in structure and floristic composition. Due to their endemic distribution, Italy carries a heavy responsibility for their maintenance in a good conservation status.

\subsection{Inland sanddrift and dune with siliceous grassland (E1.9b)}

This habitat type includes open grasslands on inland sanddrift areas, dunes and other sites with poorly developed sandy, acidic and nutrient-poor soils, characterized by a pattern of small tussocks of Corynephorus canescens (L.) P. Beauv. in a matrix of lichens, mosses and open sand. In Italy, characteristic vascular plants are Agrostis capillaris L., Logfia minima (Sm.) Dumort., Pilosella officinarum Vaill., Hypochaeris radicata L., Jasione montana L., Rumex acetosella L., Scleranthus perennis L. and Teesdalia nudicaulis (L.) W.T. Aiton. Characteristic lichens are: Cetraria aculeata (Schreb.) Fr., Cladonia portentosa (Dufour) Coem., Cladonia foliacea (Huds.) Willd., Cladonia furcata (Huds.) Schrad. and Stereocaulon condensatum Hoffm. (Gheza et al. 2015, 2016). Typical bryophytes are Ceratodon purpureus (Hedw.) Brid., Polytrichum piliferum Hedw. and Racomitrium canescens (Hedw.) Brid. The habitat occurs in mosaics with heathland, scrub and forest, and is mainly distributed in the N-C European lowland of the Netherlands, Germany and Poland. It is also found in lowlands of S-C Europe, Baltic states, Southern Sweden and Denmark, Western Ukraine and Southwest France. It occurs rarely in the UK, Iberian Peninsula and Italy. Here, the habitat is restricted and isolated, and occupies sites at the southern border of its main distribution range localized in the western Po Plain (Assini et al. 2013). For this reason, the Italian communities lack typical C-European species and can be differentiated by unique species combinations, including Atlantic, sub-Mediterranean, orophyte and steppic elements.

At the EU28 level, only 13 out of 22 countries provided data on the current area, allowing an assessment with medium confidence. The habitat was Endangered for EU28 and EU28+ based on criterion A1, due to its decreasing 
trend in the last 50 years $(-80 \%)$. The long-term trend for EU28 and EU28+ was also decreasing (-83\%).

The main threatening factor is natural succession toward more closed grassland habitats on better developed soils, followed by heathlands, shrublands and finally forests. Eutrophication by atmospheric nitrogen input is a second major threat, as it speeds up the natural succession and also might facilitate invasion of competitive non-native [like the moss Campylopus introflexus (Hedw.) Brid.] and native species. Invasion by aliens may represent another threat. Recently, the negative effect of Sylvilagus floridanus and trampling was highlighted in Italy at the local scale (Gheza et al. 2017). Additionally, a major criticality of this habitat is its fragmentation. Italy holds a great responsibility in preserving it, due to its peculiar composition and relictual presence.

\subsection{Mediterranean mountain Betula and Populus tremula woodland on mineral soil (G1.9b)}

This habitat type includes open woody communities growing from the Meso-sub-Mediterranean to the supra-Mediterranean thermo-climatic belts. The plant communities characterized by the dominance of Populus tremula $\mathrm{L}$. are spread in C-S Apennines and Mt. Etna (Sicily), above $600 \mathrm{~m}$ of altitudes. In C-S Apennines, they constitute permanent woodlands or successional stage in contact with mesophilous woods growing on deep, fresh, well-drained and slightly acidic soils. Diagnostic species are mostly represented by Acer opalus Mill. subsp. obtusatum (Waldst. et Kit. ex Willd.) Gams, Cytisus hirsutus L., Prunus avium (L.) L. and Rubus canescens DC. On Mt. Etna, the aspen communities have their optimal development between 1200 and $1600 \mathrm{~m}$ a.s.l. Their scattered distribution, localization on small and narrow valleys featured by rather primitive volcanic soils, as well as biogeographic reasons (being at the southern limit of their distribution range) make the Etnean aspen woods relict peripheral populations. Diagnostic species are mesophilous elements such as Elymus panormitanus (Parl.) Tzvelev, Brachypodium sylvaticum (Huds.) P. Beauv., Daphne laureola L. and Vicia cassubica L. The Betula aetnensis-dominated plant communities are also included in this habitat. The key species (B. aetnensis Raf.) is a narrow endemic birch that, similarly to other European trees, survived the Last Glacial Maximum (LGM) in relatively narrow refugial stands. The Etnean birch communities are circumscribed to the N-E slope of Mt. Etna ranging from 1400 up to $2000 \mathrm{~m}$ a.s.l., where soil evolution is hampered by the severe environmental conditions, as well as by the frequent volcanic activity, particularly tephra falls. Such open woods are floristically poor and featured by few other orophilous species, such as Adenocarpus complicatus (L.) J. Gay subsp. bivonae (C. Presl) Peruzzi and Cephalanthera longifolia (L.) Fritsch. For Italy, this habitat is referred to the alliances Aceri obtusati-Populion tremulae Taffetani 2000 and Pino calabricae-Quercion congestae Brullo, Scelsi, Siracusa and Spampinato 1999 p.p.

In Europe, this habitat occurs also in Spain and Corsica with a total area of $37 \mathrm{~km}^{2}$, while in Italy it is very localized, being circumscribed to a total area of $6 \mathrm{~km}^{2}$ (Brullo et al. 2012), roughly representing $16 \%$ of the total area. Italy and, particularly, Sicily host the southernmost and easternmost stands of its distribution range.

At European level (EU28) the habitat has been assessed as Least Concern (LC), but considering that in Italy it occupies a really narrow area, mostly localized on Mt. Etna, a true Mediterranean mountain where climate change particularly affects the mountain tree-dominated phytocoenosis (e.g., by warming, snow cover reduction, etc.), it should predictably be classified at least as vulnerable under Criterion B. In addition, the frequency of explosive volcanic activity of Mt. Etna is significantly increasing over the last 20 years, thus affecting composition and texture of volcanic soils and, consequently, vegetation development.

Considering the restricted distribution range of the habitat, as well the impacts linked both to unauthorized grazing animals and even more aggressive pathogens, particularly the mushrooms Armillaria mellea (Vahl) P. Kumm. and Heterobasidion annosum (Fr.) Bref., it should deserve more indepth investigations and scientifically based conservation actions. Main factors contributing to past loss/degradation are climate change, changes in abiotic conditions, silviculture, forestry, forest and plantation management and use, grazing in forests/woodland, volcanic activity and introduction of disease (microbial pathogens).

\subsection{Mediterranean and temperate volcanic field (H6.1)}

This habitat type occurs on the volcanic areas of the Mediterranean and Macaronesian regions and is typically characterized by pioneer, floristically poor and endemic-rich biocoenoses. Soils are very primitive, eroded and, as such, reflect with unusual fidelity the chemical composition of the bedrock. The severe ecological conditions hamper the development of soils, and hence the habitat usually looks very stony, with a feeble accumulation of finer particles wherever conditions become slightly better. Intense solar radiation, remarkable daily temperature variations, long-lasting snow cover and mechanical disturbances caused by strong winds are usual conditions for this habitat type. Vegetation typically is scattered and discontinuous with very low cover values $(<25 \%)$, chiefly dominated by few, relic vascular plants. Large areas are completely unvegetated or only occupied by a cryptogamic vegetation. The most frequent vascular plants are Cerastium tomentosum L., Anthemis aetnensis 
Schouw ex Spreng., S. perennis L. subsp. vulcanicus (Strobl) Bég., Rumex aetnensis C. Presl, Senecio squalidus L. subsp. aethnensis (Jan ex DC.) Greuter, Saponaria sicula Raf. and Hypochaeris robertia (Sch. Bip.) Fiori. Some bryophytes (e.g., Isopterygium tenerum (Sw.) Mitt., Campylopus pilifer Brid., Calymperes erosum Müll. Hal., etc.) and lichens, such as Stereocaulon vesuvianum Pers., are widely spread. This habitat type is found on recently deposited volcanic scoriae (tephra), lava flows or orifices in volcanic areas emitting hot gases and vapors. At lower altitudes or where ecological conditions are more suitable, it is dynamically connected with the hemicrypto-chamaephytic plant communities dominated by dwarf, thorny, cushion-like species and/or grasses or contiguous to phanerophytic communities chiefly dominated by conifers. The great phytogeographical and scientific value of this habitat is given by the high number of relic, mostly endemic, taxa. For Italy, it is referred to the alliances Rumici-Astragalion siculi Poli 1965, Linarion purpureae Brullo 1984, Sclerantho-Myosotidion incrassatae Brullo et al. 2001, Campylopodion vaporarii Brullo et al. 2004 ex Puglisi and Privitera 2012.

At the EU28 level, this habitat occurs also in Spain (Canary Islands) and Portugal (mainland and Azores) with a total area of $214 \mathrm{~km}^{2}$. In Italy, it is very localized and strictly linked to the volcanic features occurring in Sicily and Campania, and marginally in Latium and Tuscany (Brullo et al. 2005) with a total area of $168 \mathrm{~km}^{2}$ (i.e., $80 \%$ of the total European area). Although no quantitative data of this habitat over the last 50 years are available, the expert assessment reported on some changes $( \pm 10 \%)$ mostly due to natural dynamics (new lava flows versus succession toward other habitats). The quantitative trend is therefore considered as stable or slightly negative. With regard to its geographical distribution, it is above the thresholds for Criterion B, thus placing it within the category Least Concern. However, considering that more than three-quarters of its total surface is hosted in the Italian territory, Italy holds a serious national responsibility for its conservation. Urban sprawl, residential and commercial development and other infrastructure (e.g., roads, car parks) are the most threatening menaces for this habitat type.

\section{Discussion, criticalities and future perspectives: toward an Italian Red List of Habitats}

With its $302,073 \mathrm{~km}^{2}$, Italy is the tenth largest country in Europe (the seventh in EU28) based on its surface (Eurostat 2015), but stands among the top positions as far as biodiversity is concerned (Blasi et al. 2005). The extraordinary variability of climatic, geological and biogeographical features is reflected by the high rate of EU-RLH habitat types detected in its territory, accounting for more than two-thirds of all TFH surveyed throughout Europe (Janssen et al. 2016). Indeed, the assessment confirms Italy as one of the European countries with the highest biodiversity. In this frame, some general comments could be highlighted.

Comparing the representativeness of the macro-categories, it appears that the "Coastal" habitats are the less represented in Italy in relation to the European variety. This is possibly due to a predefined rigid geographical classification of the TFH types, based on the distribution of the main European seas (Black Sea, Mediterranean Sea, Baltic Sea, Atlantic coasts) which neglected a number of actual floristic and biogeographic differentiations (see, e.g., Agır et al. 2014; Del Vecchio et al. 2018).

On the contrary, all the "Freshwater" habitat types are present in Italy, confirming that the plant communities related to wet ecosystems are mostly azonal and not so strictly linked to climatic and biogeographic factors.

Other types holding high regional biogeographic variability (especially in the macro-categories E, F and $\mathrm{H}$ ) appear largely represented in Italy. However, their variability does not often find room in the used TFH typology, which adopted wide definitions and in some case really too broad to reflect the local floristic and phytocoenotic peculiarities (a well-known issue also with the HD, see, e.g., Pasta and La Mantia 2009; Marcenò 2017). Indeed, at the national scale, some TFH are more emblematic and/or representative than others, being exclusive to the Italian territory (e.g., the endemic E1.1e "Perennial rocky grassland of the Italian Peninsula" or the subendemic G1.Ba "Alnus cordata woodland", see Cancellieri et al. 2017). The same could be said for those almost exclusive types which, although present in other countries, hold the largest part of their range in Italy, such as the habitat H6.1 "Mediterranean and Temperate active and recent volcanic features", featured by relic vascular plants with a very restricted range and occurring in Italy for almost $80 \%$ of its whole European distribution area (EU28). Therefore, specific efforts for maintaining these habitats in an adequate state of conservation are a crucial Italian responsibility.

The conservation (or threat) status assessment should be clearly distinguished from the conservation priorities, which have to take into account not only the scientific evaluation but also the normative issues, the need for action and the related cost-effectiveness (Rodríguez et al. 2011; Berg et al. 2014).

It should be emphasized that at different scales, e.g., locally or regionally, the degree of threat of a habitat may be higher (or lower) than at the European scale (Janssen et al. 2016). In fact, it is widely recognized that the spatial scale of analysis can seriously affect the threshold patterns, both for species and habitats (Mac Nally et al. 2002; Huggett 2005; Gigante et al. 2016a). This is the reason 
why the development of national subtypes is a basic need for a realistic and effective assessment at the national scale (Berg et al. 2014). At the same time, this is the only way to give value to the local and specific facets of biodiversity, which as a matter of fact inevitably fade away through the wide meshes of a continental-scale analysis. From this necessary refinement of knowledge based on the scale of the assessment, the role of national responsibility arises (Schmeller et al. 2012, 2014).

As concerns the level of threat, this first application of the habitat red-listing protocol at the European level highlights a rather widespread condition of decline for natural and seminatural habitats in the Italian territory, particularly critical for some specific types. The trends identified at the European level are overall confirmed: among the seven macrocategories considered in the assessment, the most critical ones being "Mires and bogs", "Grasslands", "Freshwater" and "Coastal" types, where significant numbers of threatened habitats are concentrated. The observed low level of threat of the shrubby vegetation, which rather shows quantitative increasing processes, has its counterpart in the high threat rate of the herbaceous habitats, which have largely been replaced by shrubs and forests as a consequence of the abandonment of the traditional agro-silvo-pastoral land uses combined with the natural successional dynamism (Viciani et al. 2017).

The large majority of the assessed habitats are declining both in extent and quality for different reasons, in Europe as well as in Italy. Among the most prominent pressures and threats, we can mention intensive farming, agricultural intensification and use of biocides and fertilizers; pollution, urbanization and infrastructure development; drainage, alteration of hydrologic systems and wetland reclamation; abandonment of traditional practices; invasion of alien plants and animals, and changes in land use; climate change. However, these pressures and threats act at different spatial and temporal scales and largely vary across the different habitat types (see, e.g., Bertacchi et al. 2016; Pignatti et al. 2015).

Since the protocol adopted for the EU-RLH requires both qualitative and quantitative data to be matched with quantitative thresholds (Keith et al. 2013; Bland et al. 2017, IUCN 2016; Janssen et al. 2016), the lack of updated, exhaustive knowledge and the many existing gaps severely affected the red-listing process. This is particularly true for Italy, where the poor quantitative knowledge on past and present trends remains the major criticality. Other European countries have a robust tradition of long-term programs of territorial studies and monitoring, indispensable to understand habitat and ecosystem trends (Gray 1980; Vos et al. 2000). In spite of some exemplary cases of nature conservation, Italy developed a slow and fragmented process of acknowledgment of its floristic-vegetational identity only in the last decades, mostly thanks to the actions related to the European
Directive 92/43/EEC which strongly enhanced biodiversity safeguard.

From the methodological point of view, the EU-RLH represents a landmark since it used the habitat intended as a plant community as the assessment unit. Plant communities are operational units which form the mosaic of the vegetation cover (Dengler et al. 2008). Differently from species (or at a notably faster rate), their identity changes in time concomitant with the environmental changes, from natural (e.g., physico-chemical processes) to anthropogenic ones (e.g., land-use transformations) (Berg et al. 2014). Stands of vegetation can be recognized and delimitated based on specific characteristics (such as structural, physiognomic and floristic traits) and their discontinuity with the surrounding vegetation (van der Maarel and Franklin 2013). For these reasons, plant species assemblages and vegetation types can be effectively used as proxies for ecosystems or habitats (Gigante et al. 2016a, b).

The community level may be efficiently used as a synthetic representative of various aspects of biological diversity (Kontula and Raunio 2009; Izco 2015). The concept of habitat is explicitly regarded as an operational synonym of ecosystem type (Nicholson et al. 2009; Bland et al. 2017) and in recent years the habitat concept based on plant communities has acquired a central role for biodiversity conservation (Berg et al. 2014; Gigante et al. 2016b). Even those protocols adopting large-scaled assessment units, such as 'ecosystems' or 'land environments' (e.g., Keith et al. 2013; Walker et al. 2006), mostly refer to 'plant species assemblages' or 'vegetation types' as proxies for ecosystems or habitats. When the assessment approach relies only on the theoretical concept of ecosystem (e.g., Keith et al. 2013, 2017; Rodríguez et al. 2015; IUCN 2016), a relatively abstract model which intrinsically owns multiple, nested scales and many potential different criteria of definition, the spatial dimension is definitely too heterogeneous to allow a clear and univocal definition of the assessment unit, not to mention a robust assessment of its conservation state, as also noticed by Boitani et al. (2015). Indeed, according to the IUCN (2016) definition, ecosystems can be related to different concepts, such as "habitat types, ecosystems, ecological communities, biomes".

On the other hand, plant community-based habitat types, with their spatially recognizable patches and a clear correspondence, in most cases, to the phytosociological concept of alliance, seem more suitable as unequivocal assessment units, as well as a robust, clearly detectable and measurable object of assessment. The alliance level was suggested as the most suitable standard rank for a detailed nationwide overview (Biondi et al. 2012) and has been used several times to indicate the ecological context for threatened species and habitats (Papastergiadou et al. 1997; Rodwell et al. 2002; Stanova 2003; Angiolini et al. 2017). 
The EUNIS-based typology is consistent both with the habitat concept of the European Directives and with other classification systems (Commission of the European Communities 1991; European Commission 1992, 2013; Rodwell et al. 2002; Evans 2006, 2010; Biondi et al. 2012; Bunce et al. 2013; Gigante et al. 2016a, b; Viciani et al. 2016), thereby being in line with the many recent efforts to develop interoperability tools between different types of habitats and plant community classifications (e.g., Rodwell et al. 2002; Schaminée et al. 2012, 2013).

\section{Final remarks}

The assessment of the conservation status of species and habitats is one of the main instruments in the general attempt to reduce the global loss of biodiversity and related ecosystem services adopted at the European level and meeting the targets of the EU 2020 Biodiversity Strategy (European Commission 2011). The EU-RLH complements the reporting activity requested by Article 17 of the European Directive 92/43/EEC, as it covers a much wider set of habitats than those listed in Annex I. Indeed, the EU-RLH provides for the first time a systematic and comprehensive overview of the conservation state of all European natural and semi-natural habitats. Despite some issues that need to be improved, the project stands as an outstanding effort aiming at coordinating and harmonizing the knowledge on habitat conservation both at the national and continental scale, thus setting out priorities and laying the basis for further joint researches and, above all, highlighting the huge information gap that needs to be filled in the near future.

\section{References}

Agır SU, Kutbay HG, Karaer F, Surmen B (2014) The classification of coastal dune vegetation in Central Black Sea Region of Turkey by numerical methods and EU habitat types. Rend Fis Acc Lincei 25:453-460. https://doi.org/10.1007/s12210-014-0328-7

Angelini P, Augello R, Bagnaia R, Bianco P, Capogrossi R, Cardillo A, Ercole S, Francescato C, Giacanelli V, Laureti L, Lugeri F, Lugeri N, Novellino E, Oriolo G, Papallo O, Serra B (2009) Il progetto Carta della Natura. Linee guida per la cartografia e la valutazione degli habitat alla scala 1:50.000. ISPRA, p 128. ISBN 978-88-448-0381-0

Angiolini C, Viciani D, Bonari G, Lastrucci L (2017) Habitat conservation prioritization: a floristic approach applied to a Mediterranean wetland network. Plant Biosyst 151(4):598-612

Assini S, Mondino GP, Varese P, Barcella M, Bracco F (2013) A phytosociological survey of the Corynephorus canescens (L.) Beauv. communities of Italy. Plant Biosyst 147(1):64-78

Bagella S, Caria MC (2013) Sensitivity of ephemeral wetland swards with Isoetes histrix Bory to environmental variables: implications for the conservation of Mediterranean temporary ponds. Aquat Conserv 23(2):277-290. https://doi.org/10.1002/aqc.2290
Bagella S, Gascón S, Filigheddu R, Cogoni A, Boix D (2016) Mediterranean Temporary Ponds: new challenges from a neglected habitat. Hydrobiologia 782(1):1-10

Baillie JEM, Hilton-Taylor C, Stuart SN (2004) IUCN red list of threatened species. a global species assessment. IUCN, Gland

Balmford A, Bruner A, Cooper P, Costanza R, Farber S, Green RE, Jenkins M, Jefferiss P, Jessamy V, Madden J, Munro K, Myers N, Naeem S, Paavola J, Rayment M, Rosendo S, Roughgarden J, Trumper K, Turner KT (2002) Economic reasons for conserving wild nature. Science 297:950-953

Berg C, Abdank A, Isermann M, Jansen F, Timmermann T, Dengler J (2014) Red Lists and conservation prioritization of plant communities-a methodological framework. Appl Veg Sci 17(3):504-515

Bertacchi A, Zuffi MAL, Lombardi T (2016) Foredune psammophilous communities and coastal erosion in a stretch of the Ligurian sea (Tuscany, Italy). Rend Fis Acc Lincei 27:639-651. https://doi.org/10.1007/s12210-016-0543-5

Biondi E, Blasi C (2015) Prodromo della Vegetazione Italiana. MATTM. www.prodromo-vegetazione-italia.org. Accessed 20 Apr 2017

Biondi E, Blasi C, Burrascano S, Casavecchia S, Copiz R, Del Vico E, Galdenzi D, Gigante D, Lasen C, Spampinato G, Venanzoni R, Zivkovic L (2009) Manuale Italiano di interpretazione degli habitat della Direttiva 92/43/CEE. SBI, MATTM, DPN. http:// vnr.unipg.it/habitat. Accessed 30 Sept 2017

Biondi E, Burrascano S, Casavecchia S, Copiz R, Del Vico E, Galdenzi D, Gigante D, Lasen C, Spampinato G, Venanzoni R, Zivkovic L, Blasi C (2012) Diagnosis and syntaxonomic interpretation of Annex I Habitats (Dir. 92/43/EEC) in Italy at the alliance level. Plant Sociol 49(1):5-37

Biondi E, Blasi C, Allegrezza M, Anzellotti I, Azzella MM, Carli E, Casavecchia S, Copiz R, Del Vico E, Facioni L, Galdenzi D, Gasparri R, Lasen C, Pesaresi S, Poldini L, Sburlino G, Taffetani F, Vagge I, Zitti S, Zivkovic L (2014) Plant communities of Italy: the vegetation prodrome. Plant Biosyst 148(4):728-814

Biserkov V (ed) (2011) Red data book of the Republic of Bulgaria. Bulgarian Academy of Sciences and Ministry of Environment and Water. http://e-codb.bas.bg/rdb/en/vol3. Accessed 12 Apr 2015

Blab J, Riecken U, Ssymank A (1995) Proposal on a criteria system for a National Red Data Book of Biotopes. Landsc Ecol 10:41-50

Bland LM, Keith DA, Miller RM, Murray NJ, Rodríguez JP (eds) (2017) Guidelines for the application of IUCN Red List of Ecosystems Categories and Criteria, Version 1.1. IUCN, Gland, Switzerland. IX $+99 \mathrm{pp}$

Blasi C (ed) (2010) La Vegetazione d'Italia. Palombi Ed. Roma, p 539. ISBN 978-88-6060-290-9

Blasi C, Boitani L, La Posta S, Manes F, Marchetti M (2005) Stato della Biodiversità in Italia. Contributo alla Strategia Nazionale per la Biodiversità. Palombi Ed., p 466. ISBN: 88-7621-514-X

Boitani L, Mace GM, Rondinini C (2015) Challenging the scientific foundations for an IUCN Red List of Ecosystems. Conserv Lett $8(2): 125-131$

Brullo S, Cormaci A, Giusso del Galdo G, Guarino R, Minissale P, Siracusa G, Spampinato G (2005) A syntaxonomical survey of the Sicilian dwarf shrub vegetation belonging to the class Rumici-Astragaletea siculi. Ann Bot (Roma) 5:57-104

Brullo C, Brullo S, Giusso del Galdo G, Guarino R, Siracusa G, Sciandrello S (2012) The class Querco-Fagetea sylvaticae in Sicily: an example of boreo-temperate vegetation in the central Mediterranean region. Ann Bot (Roma) 2:19-38

Bunce RGH, Bogers MMB, Evans D, Halada L, Jongman RHG, Mucher CA, Bauch B, de Blust G, Parr TW, Olsvig-Whittaker L (2013) The significance of habitats as indicators of biodiversity and their links to species. Ecol Indic 33:19-25 
Butchart SHM, Stattersfield AJ, Bennun LA, Shutes SM, Akçakaya HR, Baillie JEM, Stuart SN, Hilton-Taylor C, Mace GM (2004) Measuring global trends in the status of biodiversity: Red List Indices for birds. PLoS Biol 2:2294-2304

Cafaro P, Primack R (2014) Species extinction is a great moral wrong. Biol Conserv 170:1-2

Cancellieri L, Caneva G, Cutini M (2017) Phytosociology and ecology of the Mediterranean forests ecosystems in the Amalfi Coast (Monti Lattari, Italy). Rend Fis Acc Lincei 28:651-671. https:// doi.org/10.1007/s12210-017-0635-x

CITES (1973) Convention on international trade in endangered species of Wild Fauna and Flora. Signed at Washington, D.C., on 3 March 1973. Amended at Bonn, on 22 June 1979. http://www. cites.org/eng/disc/text.php. Accessed 16 Nov 2017

Commission of the European Communities (1991) Habitats of the European Community. CORINE biotopes manual. Commission of the European Communities, Luxembourg

Cowling RM, Knight AT, Faith DP, Ferrier S, Lombard AT, Driver A, Rouget M, Maze K, Desmet PG (2004) Nature conservation requires more than a passion for species. Conserv Biol 18:1674-1676

Davies CE, Moss D, Hill MO (2004) EUNIS Habitat Classification Revised 2004. Report to European Environment Agency, European Topic Center on Nature Protection and Biodiversity

Del Vecchio S, Fantinato E, Janssen JAM, Bioret F, Acosta A, Prisco I, Tzonev R, Marcenò C, Rodwell J, Buffa G (2018) Biogeographic variability of coastal perennial grasslands at the European scale. Appl Veg Sci. https://doi.org/10.1111/avsc.12356

Dengler J, Chytrý M, Ewald J (2008) Phytosociology. In: Jørgensen SE, Fath BD (eds) General ecology. Vol. 4 of Encyclopedia of ecology, vol 5. Elsevier, Oxford, pp 2767-2779

EEA (2015) Linking in situ vegetation data to the EUNIS habitat classification: results for forest habitats, p 33. ISBN 978-92-9213703-8. https://doi.org/10.2800/88900

Ernandes P, Gigante D, Beccarisi L, Marchiori S, Venanzoni R, Zuccarello V (2017) Isoëto-Nanojuncetea in Puglia (S-Italy): first phytosociological survey. Plant Sociol 54(2):23-36. https://doi. org/10.7338/pls2017542/03

Essl F, Egger G, Ellmauer T (2002) Rote liste gefährdeter biotoptypen österreichs. Konzept. Umweltbundesamt GmbH, Wien

EUNIS (2007) EUNIS Habitat Classification. www.eea.europa.eu/ themes/biodiversity/eunis/eunis-habitat-classification. Accessed 20 Sept 2017

European Commission (1992) Council Directive 92/43/EEC of 21 May 1992 on the conservation of natural habitats and of wild fauna and flora. Off J Eur Union 206:7-50

European Commission (2011) Communication from the commission to the European parliament, the council, the economic and social committee and the committee of the regions. Our life insurance, our natural capital: an EU biodiversity strategy to 2020. Brussels, 3.5.2011. COM 244 final, p 16

European Commission (2013) Interpretation manual of European Union habitats-EUR28. Brussels

European Environmental Agency (2007) CLC2006 technical guidelines. EEA Technical report, 17/2007, Copenhagen, p 66. ISBN 978-92-9167-968-3

Eurostat (2015) Area by NUTS 3 region. EUROBASE DATA EXPLORER v3.4.1. http://appsso.eurostat.ec.europa.eu/nui/ submitViewTableAction.do. Accessed 20 Jan 2018

Evans D (2006) The habitats of the European union habitats directive. Biol Environ 106b(3):167-173

Evans D (2010) Interpreting the habitats of Annex I. Past, present and future. Acta Bot Gallica 157(4):677-686

Feola S, Carranza ML, Schaminée JHJ, Janssen JAM, Acosta ATR (2011) EU habitats of interest: an insight into Atlantic and
Mediterranean beach and foredunes. Biodivers Conserv 20(7):1457-1468

Galdenzi D, Pesaresi S, Casavecchia S, Zivkovic L, Biondi E (2012) The phytosociological and syndynamical mapping for the identification of High Nature Value Farmland. Plant Sociol 49(2):59-69

Genovesi P, Angelini P, Bianchi E, Dupré E, Ercole S, Giacanelli V, Ronchi F, Stoch F (2014) Specie e habitat di interesse comunitario in Italia: distribuzione, stato di conservazione e trend. ISPRA, Serie Rapporti, 194/2014, p 330. ISBN 978-88-4480644-6. http://cdr.eionet.europa.eu/it/eu/art17/envupyjhw. Accessed 30 Apr 2017

Gheza G, Assini S, Valcuvia M (2015) Contribution to the knowledge of lichen flora of inland sand dunes in the Western Po Plain (N Italy). Plant Biosyst 149(2):307-314

Gheza G, Assini S, Valcuvia M (2016) Terricolous lichen communities of Corynephorus canescens grasslands of Northern Italy. Tuexenia 36:121-142

Gheza G, Assini S, Marini L, Nascimbene J (2017) L'impatto di lagomorfi alloctoni e del calpestio umano nelle praterie aride ricche di crittogame. In: Buldrini F, Chiarucci A, Donati D, Lelli C, Nascimbene J, Pezzi G, Velli A (eds), Atti del $51^{\circ}$ Congresso della Società Italiana di Scienza della Vegetazione, Servizi Ecosistemici e Scienza della Vegetazione, Bologna, 20-21 aprile 2017, p 53. ISBN 9788898010677. https://doi.org/10.6092/unibo /amsacta/5617

Gigante D, Attorre F, Venanzoni R, Acosta ATR, Agrillo E, Aleffi M, Alessi N, Allegrezza M, Angelini P, Angiolini C, Assini S, Azzella MM, Bagella S, Biondi E, Bolpagni R, Bonari G, Bracco F, Brullo S, Buffa G, Carli E, Caruso G, Casavecchia S, Casella L, Cerabolini BEL, Ciaschetti G, Copiz R, Cutini M, Del Vecchio S, Del Vico E, Di Martino L, Facioni L, Fanelli G, Foggi B, Frattaroli AR, Galdenzi D, Gangale C, Gasparri R, Genovesi P, Gianguzzi L, Gironi F, Giusso del Galdo G, Gualmini M, Guarino R, Lasen C, Lastrucci L, Maneli F, Pasta S, Paura B, Perrino EV, Petraglia A, Pirone G, Poponessi S, Prisco I, Puglisi M, Ravera S, Sburlino G, Sciandrello S, Selvaggi A, Spada F, Spampinato G, Strumia S, Tomaselli M, Tomaselli V, Uzunov D, Viciani D, Villani M, Wagensommer RP, Zitti S (2016a) A methodological protocol for Annex I Habitats monitoring: the contribution of vegetation science. Plant Sociol 53(2):77-87. https://doi.org/10.7338/pls2016532/06

Gigante D, Foggi B, Venanzoni R, Viciani D, Buffa G (2016b) Habitats on the grid: the spatial dimension does matter for redlisting. J Nat Conserv 32:1-9. https://doi.org/10.1016/j.jnc.2016.03.007

Gray JS (1980) Why do ecological monitoring? Mar Pollut Bull 11(3):62-65

Gubbay S, Sanders N, Haynes T, Janssen JAM, Rodwell JR, Nieto A, García Criado M, Beal S, Borg J, Kennedy M, Micu D, Otero M, Saunders G, Calix M (2016) European Red List of Habitats. Part 1 Marine habitats. Publications Office of the European Union, Luxembourg. https://doi.org/10.2779/032638 (ISBN 978-92-79-61586-3)

Huggett HJ (2005) The concept and utility of 'ecological thresholds' in biodiversity conservation. Biol Conserv 124:301-310

IUCN (2012) IUCN Red List categories and criteria, version 3.1, 2nd edn. IUCN, Gland, Switzerland and Cambridge, UK. IV + 32 pp

IUCN (2013) Guidelines for using the IUCN Red List categories and criteria. Version 10.1. Prepared by the Standards and Petitions Subcommittee

IUCN (2016) An introduction to the IUCN Red List of Ecosystems: the categories and criteria for assessing risks to ecosystems. IUCN, Gland (ISBN: 978-2-8317-1787-6)

Izco J (2015) Risk of extinction of plant communities: risk and assessment categories. Plant Biosyst 149(3):589-602 
Janssen JAM, Rodwell JS, Criado MG, Gubbay S, Haynes T, Nieto A, Sanders N, Landucci F, Loidi J, Ssymank A, Tahvanainen T, Valderrabano M, Acosta A, Aronsson M, Arts G, Attorre F, Bergmeier E, Bijlsma RJ, Bioret F, Biţă-Nicolae C, Biurrun I, Calix M, Capelo J, Čarni A, Chytrý M, Dengler J, Dimopoulos P, Essl F, Gardfjell H, Gigante D, Giusso del Galdo G, Hájek M, Jansen F, Jansen J, Kapfer J, Mickolajczak A, Molina JA, Molnár Z, Paternoster D, Piernik A, Poulin B, Renaux B, Schaminée JHJ, Šumberová K, Toivonen H, Tonteri T, Tsiripidis I, Tzonev R, Valachovič M (2016) European Red List of Habitats. Part 2. Terrestrial and freshwater habitats. Publications Office of the European Union, Luxembourg. https://doi.org/10.2779/091372 (ISBN 978-92-79-61588-7)

Javeline D, Hellmann JJ, Cornejo RC, Shufeldt G (2013) Expert opinion on climate change and threats to biodiversity. Bioscience 63(8):666-673

Keith DA, Rodríguez JP, Rodríguez-Clark KM, Nicholson E, Aapala $\mathrm{K}$, Alonso A, Asmussen M, Bachman S, Bassett A, Barrow EG, Benson JS, Bishop MJ, Bonifacio R, Brooks TM, Burgman MA, Comer P, Comín FA, Essl F, Faber-Langendoen D, Fairweather PG, Holdaway RJ, Jennings M, Kingsford RT, Lester RE, Mac Nally R, McCarthy MA, Moat J, Nicholson E, Oliveira-Miranda MA, Pisanu P, Poulin B, Riecken U, Spalding MD, ZambranoMartínez S (2013) Scientific foundations for an IUCN Red List of Ecosystems. PLoS One 8(5):e62111

Keith DA, Rodríguez JP, Brooks TM, Burgman MA, Barrow EG, Bland L, Comer PJ, Franklin J, Link J, McCarthy MA, Miller RM, Murray NJ, Nel J, Nicholson E, Oliveira-Miranda MA, Regan TJ, Rodríguez-Clark KM, Rouget M, Spalding MD (2017) The IUCN Red List of Ecosystems: motivations, challenges, and applications. Conserv Lett 8(3):214-226

Kontula T, Raunio A (2009) New method and criteria for national assessments of threatened habitat types. Biodivers Conserv 18:3861-3876

Krueger T, Page T, Hubacek K, Smith L, Hiscock K (2012) The role of expert opinion in environmental modelling. Environ Model Softw 36:4-18

Lastrucci L, Bonari G, Angiolini C, Casini F, Giallonardo T, Gigante D, Landi M, Landucci F, Venanzoni R, Viciani D (2014) Vegetation of Lakes Chiusi and Montepulciano (Siena, central Italy): updated knowledge and new discoveries. Plant Sociol 51(2):29-55

Lindgaard A, Henriksen S (2011) The 2011 Norvegian Red List for ecosystems and habitat types. Norwegian Biodiversity Information Centre, Trondheim

Lucarini D, Gigante D, Landucci F, Panfili E, Venanzoni R (2015) The anArchive taxonomic checklist for Italian botanical data banking and vegetation analysis: theoretical basis and advantages. Plant Biosyst 149(6):958-965

Mac Nally R, Bennett AF, Brown GW, Lumsden LF, Yen A, Hinkley S, Lillywhite P, Ward DA (2002) How well do ecosystem-based planning units represent different components of biodiversity? Ecol Appl 12(3):900-912

Mace GM, Collar NJ, Gaston KJ, Hilton-Taylor C, Akcakaya HR, Leader-Williams N, Milner-Gulland EJ, Stuart SN (2008) Quantification of extinction risk: IUCN's system for classifying threatened species. Conserv Biol 22:1424-1442

Marcenò C (2017) Natura 2000 in Italy: some ideas for the French project CarHAB. Doc Phytosociol 6:146-154

McCarthy MA, Thompson CJ, Garnett ST (2008) Optimal investment in conservation of species. J Appl Ecol 45:1428-1435

Millennium Ecosystem Assessment (2005) Ecosystems and human wellbeing: biodiversity synthesis. World Resources Institute, Washington, DC

Moravec J, Balátová-Tuláčková E, Hadač E, Hejný S, Jeník J, Kolbek J, Kopecký K, Krahulec F, Kropáč Z, Neuhäusl R, Rybníček
K, Vicherek J (1983) Rostlinná společenstva České socialistické republiky a jejich ohrožení. (Red list of plant communities of the Czech Republic and their endangerment.) 1. Ed. Severočeskou Přír., Suppl. (1): 1-110

Mucina L, Bültmann H, Dierßen K, Theurillat J-P, Raus T, Čarni A, Šumberová K, Willner W, Dengler J, Gavilán García R, Chytrý M, Hájek M, Di Pietro R, Iakushenko D, Pallas J, Daniëls FJA, Bergmeier E, Santos Guerra A, Ermakov N, Valachovič M, Schaminée JHJ, Lysenko T, Didukh YP, Pignatti S, Rodwell JS, Capelo J, Weber HE, Solomeshch A, Dimopoulos P, Aguiar C, Hennekens SM, Tichý L (2016) Vegetation of Europe: hierarchical floristic classification system of vascular plant, bryophyte, lichen, and algal communities. Appl Veg Sci 19(1):3-264

Nicholson E, Keith DA, Wilcove DS (2009) Assessing the conservation status of ecological communities. Conserv Biol 23:259-274

Noss RF (1996) Ecosystems as conservation targets. Trends Ecol Evol 11:351

Noss RF, LaRoe ET, Scott JM (1995) Endangered ecosystems of the United States: a preliminary assessment of loss and degradation. US Geological Survey, Washington DC

Paal J (1998) Rare and threatened plant communities of Estonia. Biodivers Conserv 7:1027-1049

Papastergiadou E, Dafis S, Dimopoulos P, Lazaridou T (1997) Syntaxonomic typology of Greek habitats. Folia Geobot Phytotax 32:335-341

Pasta S, La Mantia T (2009) La Direttiva 92/43/CEE ed il patrimonio agro-forestale, pre-forestale e forestale siciliano: alcune note critiche. Nat Siciliano 33(3-4):315-328

Pignatti E, Pignatti S, D’Angeli D, De Nicola C, Maffei L, Testi A, Tinelli A (2015) The Laurisilva as a cultural heritage: proposal for the protection of the relict of laurel forest near Ponte Renaro. Rend Fis Acc Lincei 26(Suppl 3):643-649. https://doi. org/10.1007/s12210-015-0389-2

Prisco I, Acosta ATR, Ercole S (2012) An overview of the Italian coastal dune EU habitats. Ann di Bot 2:39-48

Quézel P (1998) La végétation des mares transitoires à Isoetes en région méditerranéenne, intérêt patrimonial et conservation. Ecol Medit 24(2):111-117

Rodríguez JP, Rodríguez-Clark KM, Baillie JEM, Ash N, Benson J, Boucher T, Brown C, Burgess ND, Collen BEN, Jennings M, Keith DA, Nicholson E, Revenga C, Reyers B, Rouget M, Smith T, Spalding M, Taber A, Walpole M, Zager I, Zamin T (2011) Establishing IUCN red list criteria for threatened ecosystems. Conserv Biol 25:21-29

Rodríguez JP, Rodríguez-Clark KM, Keith DA, Barrow EG, Benson J, Nicholson E, Wit P (2012) IUCN Red List of Ecosystems. S.A.P.I.EN.S [online] 5.2. https://journals.openedition.org/sapie ns/1286. Accessed 30 Dec 2016

Rodríguez JP, Keith DA, Rodríguez-Clark KM, Murray NJ, Nicholson E, Regan TJ, Miller RM, Barrow EG, Bland LM, Boe K, Brooks TM, Oliveira-Miranda MA, Spalding M, Wit P (2015) A practical guide to the application of the IUCN Red List of Ecosystems criteria. Philos Trans R Soc B 370:20140003

Rodwell J, Schaminée JHJ, Mucina L, Pignatti S, Dring J, Moss D (2002) The Diversity of European Vegetation. An overview of phytosociological alliances and their relationships to EUNIS Habitats. Wageningen. EC-LNV Report nr. 2002/054. Ministry of Agriculture Nature Management and Fisheries, The Netherlands and European Environmental Agency

Rodwell J, Janssen J, Gubbay S, Schaminée J (2013) Red List Assessment of European Habitat Types-A feasibility study. Service Contract No. 070307/2012/624047/SER/B3, Report for the European Commission, DG Environment

Salafsky N, Salzer D, Stattersfield AJ, Hilton-Taylor C, Neugarten R, Butchart SHM, Collen B, Cox N, Master LL, O'Connor S, Wilkie D (2008) A standard lexicon for biodiversity conservation: 
unified classifications of threats and actions. Conserv Biol 22(4):897-911

Schaminée JHJ, Chytrý M, Hennekens SM, Mucina L, Rodwell JS, Tichý L (2012) Development of vegetation syntaxa crosswalks to EUNIS habitat classification and related data sets. Final report EEA/NSV/12/001

Schaminée JHJ, Chytrý M, Hennekens SM, Jiménez-Alfaro B, Mucina L, Rodwell JS, Data Contributors (2013) Review of EUNIS forest habitat classification. Report EEA/NSV/13/005

Schaminée JHJ, Chytrý M, Hennekens SM, Janssen JAM, JiménezAlfaro B, Knollová I, Mucina L, Rodwell JS, Tichý L, Dataproviders (2014) Vegetation analysis and distribution maps for EUNIS habitats. Report EEA/NSV/14/006

Schaminée JHJ, Chytrý M, Hennekens SM, Janssen JAM, JiménezAlfaro B, Knollová I, Marcenò C, Mucina L, Rodwell JS, Tichý L, Data-providers (2015) Review of grassland habitats and development of distribution maps of heathland, scrub and tundra habitats of EUNIS habitats classification. Report EEA/NSV/15/005

Schaminée JHJ, Chytrý M, Dengler J, Hennekens SM, Janssen JAM, Jiménez-Alfaro B, Knollová I, Landucci F, Marcenò C, Rodwell JS, Tichý L, Data-providers (2016) Development of distribution maps of grassland habitats of EUNIS habitat classification. Report EEA/NSS/16/005

Schmeller DS, Maier A, Bauch B, Evans D, Henle K (2012) National responsibilities for conserving habitats-a freely scalable method. Nat Conserv 3:21-44

Schmeller DS, Evans D, Lin YP, Henle K (2014) The national responsibility approach to setting conservation priorities-recommendations for its use. J Nat Conserv 22:349-357

Schulte G, Wolf-Straub R (1986) Vorläufige Rote Liste der NordrheinWestfalen gefährdete Biotope. Rote Liste der in Nordrhein-Westfalen gefährdeten Pflanzen und Tiere. Schriftenreihe der LÖLF 4:19-27

Secretariat of the Convention on Biological Diversity (2010) Global biodiversity outlook 3. Secretariat of the Convention on Biological Diversity, Montréal

Stanova V (2003) Plant Alliances. In: Witkowski ZJ, Król W, Solarz W (eds), Carpathian list of endangered species. WWF and
Institute of Nature Conservation, Polish Academy of Sciences, Vienna-Krakow. EUROPRESS, Kraków, Poland, p 64. ISBN 83-918914-0-2

Testi A, De Nicola C, Dowgiallo G, Fanelli G (2010) Correspondences between plants and soil/environmental factors in beech forests of Central Apennines: from homogeneity to complexity. Rend Fis Acc Lincei 21:27. https://doi.org/10.1007/s12210-009-0054-8

United Nations (1976) Convention on Wetlands of International Importance especially as Waterfowl Habitat. Concluded at Ramsar, Iran, 2/2/1971. UN Treaty Series N. 14583, 996:246-268

United Nations (1992) Convention on biological diversity. United Nations Conference on Environment and Development. UN Treaty Series. 1760

United Nations (2015) Sustainable development goals. United Nations, New York. http://www.un.org/sustainabledevelopment/summit/. Accessed 20 Sept 2017

Van der Maarel E, Franklin J (eds) (2013) Vegetation ecology, 2nd edn. Wiley, p 572. ISBN: 978-1-444-33888-1

Viciani D, Lastrucci L, Dell'Olmo L, Ferretti G, Foggi B (2014) Natura 2000 habitats in Tuscany (central Italy): synthesis of main conservation features based on a comprehensive database. Biodivers Conserv 23:1551-1576. https://doi.org/10.1007/s1053 1-014-0686-6

Viciani D, Dell'Olmo L, Ferretti G, Lazzaro L, Lastrucci L, Foggi B (2016) Detailed Natura 2000 and Corine Biotopes habitat maps of the island of Elba (Tuscan Archipelago, Italy). J Maps 12(3):492-502. https://doi.org/10.1080/17445 647.2015 .1044040

Viciani D, Dell'Olmo L, Gabellini A, Gigante D, Lastrucci L (2017) Landscape dynamics of Mediterranean montane grasslands over 60 years and implications for habitats conservation: a case study in the northern Apennines (Italy). Landsc Res. https://doi. org/10.1080/01426397.2017.1400526 (in press)

Vos P, Meelis E, Ter Keurs WJ (2000) A framework for the design of ecological monitoring programs as a tool for environmental and nature management. Environ Monit Assess 61(3):317-344

Walker S, Price R, Rutledge D, Lee WG (2006) Recent loss of indigenous cover in New Zealand. N Z J Ecol 30(2):169-177

\section{Affiliations}

\section{Gigante (10) A. T. R. Acosta ${ }^{2}$ - E. Agrillo ${ }^{3}$ - S. Armiraglio ${ }^{4}$ - S. Assini ${ }^{5} \cdot$ F. Attorre ${ }^{3}$ S. Bagella ${ }^{6} \cdot$ G. Buffa ${ }^{7} \cdot$ L. Casella $^{8}$. C. Giancola ${ }^{9}$. G. P. Giusso del Galdo ${ }^{10} \cdot$ C. Marcenò ${ }^{11} \cdot$ G. Pezzi ${ }^{12} \cdot$ I. Prisco ${ }^{2} \cdot$ R. Venanzoni ${ }^{1}$ (D) D. Viciani ${ }^{13}$}

\author{
A. T. R. Acosta \\ acosta@uniroma3.it \\ E. Agrillo \\ emiliano.agrillo@uniroma1.it \\ S. Armiraglio \\ botanica@comune.brescia.it \\ S. Assini \\ silviapaola.assini@unipv.it \\ F. Attorre \\ fabio.attorre@uniroma1.it \\ S. Bagella \\ sbagella@uniss.it \\ G. Buffa \\ gabriella.buffa@unive.it \\ L. Casella \\ laura.casella@isprambiente.it
}

C. Giancola

carmengiancola@gmail.com

G. P. Giusso del Galdo

g.giusso@unict.it

C. Marcenò

marcenocorrado@libero.it

G. Pezzi

giovanna.pezzi@unibo.it

I. Prisco

irene.prisco@uniroma3.it

R. Venanzoni

roberto.venanzoni@unipg.it

D. Viciani

daniele.viciani@unifi.it 
1 Department of Chemistry, Biology and Biotechnology, University of Perugia, via del Giochetto, 06122 Perugia, Italy

2 Department of Sciences, University of Roma 3, V.le Marconi 445, 00146 Rome, Italy

3 Department of Environmental Biology, Sapienza University of Rome, P.le Aldo Moro 5, 00185 Rome, Italy

4 Natural Science Museum of Brescia, via Ozanam 4, 25128 Brescia, Italy

5 Department of Earth and Environmental Science, University of Pavia, via Ferrata 1, 27100 Pavia, Italy

6 Department of Chemistry and Pharmacy, University of Sassari, via Vienna 2, 07100 Sassari, Italy

7 Department of Environmental Sciences, Informatics and Statistics, Ca' Foscari University of Venice, via Torino 155,30172 Venice, Italy
8 Istituto Superiore per la Protezione e Ricerca Ambientale, via Vitaliano Brancati 60, 00144 Rome, Italy

9 Department of Bioscience and Territory, University of Molise, Contrada Fonte Lappone snc, 86090 Pesche, Italy

10 Department of Biological, Geological and Environmental Sciences, University of Catania, via A. Longo 19, 95125 Catania, Italy

11 Department of Plant Biology and Ecology, University of the Basque Country UPV/EHU, Apdo. 644, 48080 Bilbao, Spain

12 Department of Biological, Geological and Environmental Sciences, University of Bologna, via Irnerio 42, 40126 Bologna, Italy

13 Department of Biology, University of Florence, via G. La Pira 4, 50121 Florence, Italy 